\title{
Community Empowerment Policy Analysis in the Archipelago Group Natural Resources Management
}

\author{
Lilik Sulistyowati ${ }^{1}$ \\ \{liliks@ecampus.ut.ac.id \} \\ ${ }^{1}$ Universitas Terbuka, Jakarta, indonesia
}

\begin{abstract}
Abstract. This research aims to analysis the policy of community empowerment in natural resource management. Research was conducted in Kelapa Island and Harapan Thousand Islands. Method used the case study method using a qualitative approach. The results of the study showed, (1) The condition and potential of natural and human resources, especially the level of participation in the preservation of natural resources in the form of coral reefs identified in damaged state $(20 \%)$ Cause of damage due to the degraded mangrove forest and the accumulation of household waste in the research area, $13.2 \%$ of the 100 respondents who have an income above 10,000,- IDR/day or $250.000,-$ IDR /month, it is shown that income Community is still far below Regional Minimum wage of 700,000,- IDR / month, the quality of the sea water is good enough for the cultivation of grouper, seaweed, the number of community respondents who throw garbage in the sea and area is $81 \%$; (2) factors that can affect the natural resource condition in the form of increasing population with an average growth of $3.5 \%$ per year, so that the population density reaches $3.458 / \mathrm{km}$ square, household waste affecting pollution Water quality because people throw directly into the sea both latrines and household waste (kitchen). Based on the findings, it was concluded that the community is still poor in natural resource management in the archipelago group.
\end{abstract}

Keywords: Analysis, Policy, Community Empowerment, Natural Resources

\section{INTRODUCTION}

Thousand Islands consist of a cluster of small islands and has the potential of highly productive natural resources (high productivity) and diversity such as mangroves, coral reefs, sea grass, and biota that live in it. Utilization of the Thousand Islands region that stands out is the fisheries and aquaculture and tourism. Natural resources are very limited land, while the natural resources of coastal and marine and environmental services potential.

Natural resources consist of marine and coastal resources can be recovered as coral reefs, seagrass, mangrove, demersal and pelagic fisheries while environmental services include marine transportation and tourism language. The nature of coastal ecosystem force vulnerable islands with existing problems require an integrated and comprehensive management by involving the 
local community involved and active role of local communities that need to be integrated with various agencies handling related.

Human resources generally Thousand Islands livelihood as a fisherman and as farmers seaweed, fish farmers Terapu, traders and civil servants. Poverty, lack of education and knowledge and lack of information as a result of the isolation of small islands are characteristic of small island communities. The results of the development and have not been enjoyed by people who live in remote island region. Community development is laid as an object and not as a subject of development. Thus, it takes a high attention and desire to improve the condition of coastal communities as resource managers of small islands that take place in a sustainable manner.

Some problems occurred cluster of islands including; coral reefs are damaged, water quality pollution, deforestation Mangrove, bomb fish, people throw garbage, toilets and household waste (kitchen) directly into the sea.

For all these reasons that the researchers chose to conduct research in the area of cluster islands. Some studies related to the research conducted as research conducted by Santosa which states that of the many communities the concept of community empowerment, there is one key concept that is fundamental and important that their independence in the community focused on the ability to perform and make decisions in the interests based on ownership of local resources [1]. Likewise, the results of research conducted by Erum and Hussain which says that the natural resources leads to economic growth in local communities [2].

Further based on the results of research conducted by Meyer which says that most institutional problems caused by the natural resources is corruption; the rule of law or justice issues; inefficient administration; poor regulation; lack of voice and accountability; political instability [3]. Based on several studies above, the novelty of the research is focused on the quality of sea water, income communities and islands Force participation rate in conservation of natural resources. Some concepts related to this research include; The concept of need analysis, community empowerment, and natural resources.

Policy analysis is a technique used in public administration to examine and evaluate employees in goal. It has been defined as the process of "determining the various policy achieving a goal. According Thomas and the Bull that the policy analysis is a diverse field, and the researchers used this framework in a variety of theoretical perspectives to policy-making criticism of contemporary issues, processes and policies [4]. Likewise, according to Vining and Weimer that the policy research and policy analysis differ in important ways, a policy research is a very valuable resource for policy analysis. Research policies relating to the relevant policy issues almost always played an important role in policy analysis of evidence analysis [5]. Furthermore, according to Posner and C. Cvitanovic that in the process of creating a policy, it is necessary to understand deeply about the purpose and effect of the policy [6].

Community empowerment is an attempt to provide reinforcement to the power or the public. As a process, empowerment is a series of activities to strengthen the weak groups in society, including individuals who experience poverty. According Markantonia, et al who said that the successful implementation of community development policy is to require appropriate support, structure and process for transferring power from the state to society [7]. Likewise, according to Edwards and Salvador that there are several dimensions such as policy implementation of technical, institutional, and political. Technical dimension refers to a policy or program design. Draws attention to the institutional dimension of organizational capacity, or "core capabilities organizations to implement specific changes, and the role of government in community development [8]. According Farhana et. al, who said community empowerment refers to a process that allows the community to improve control over their lives. Thus, facilitating 
empowerment at the Community level requires the collective and coordinated efforts of various groups and social institutions to increase the economic resources [9] .

Natural resources is everything that comes from nature that can be used to meet the needs of human life. According Lessmann, and Steinkraus that natural resources are a blessing for the region, but the natural resources would be a disaster if it is not keeping well [10]. Likewise, according to Zalle that natural resources may lead to improved economic performance was good, and vice versa can be disastrous for a region. Natural resources degrade the quality of the institution to postpone democratization, reducing the level of civil liberties and the weakening of the rule of law [11].

\section{RESEARCH METHOD}

The method used in this study is a case study using a qualitative approach. The case study method was used to obtain accurate information to answer the problem of this research, that the conditions and potential natural and human resources, especially the level of participation in the preservation of natural resources and the factors that may affect the condition of the natural resources in the Cluster Islands (Kelapa Island and Harapan Island). The main data sources (key informants) in this study is the community, local government archipelagoes. Resources of this will be done several methods of data collection such as interviews, documentation and observation to get as much information as possible about community empowerment policy analysis in natural resource management archipelagoes.

\section{RESULTS AND DISCUSSION}

The results of the research on the condition and potential of natural and human resources, especially the level of participation in natural resources preservation show that coral reefs as a natural resource potential in the research areas identified in damaged condition (percent closing $20 \%$ ). The cause damage to coral reefs is the degradation of mangrove forests and the accumulation of household waste in the research area. So also in the aspect of people's incomes showed that $13.2 \%$ of the 100 respondents who have income above 10.000 , - IDR / day or 250.000, - IDR / month, this suggests that people's incomes are still far below the regional minimum wage (UMR) locally 700.000, - IDR / month. This fact shows the weakness of the local economy in the area of research. While the quality of the waters around the island of Palm that shows the quality of sea water in the study areas in fairly good condition suitable for the cultivation of grouper, seaweed and others. As well as the number of respondents who throw garbage people in the sea and its surroundings are at $81 \%$, it show that the level of public awareness of the environmental quality of life is still low.

The pressure on natural resources caused by the increase in population and the fishermen understanding of the importance of environmental value and not to heed sustainability will cause damage to the surrounding environment. Impact on the degradation of seawater quality so that it can decrease the results of the capture and cultivation around the island, which in turn can reduce the economic level of society and it comes down to poverty.

In order to make natural resources (sustainable) balance, it is necessary strategically to implement empowerment programs involving the community from planning to evaluation and monitoring in program activities learning. Based on these results match the results of research conducted by Danish, et. al, that the excessive use of natural resources, through agriculture, deforestation, and mining can have a negative impact on the environment [12]. Likewise, the 
results of research conducted by Armey, and M. Mc Nab that the abundance of natural resources can have an adverse effect on the environment. If these resources are not well managed [13].

The results of any factors that could affect natural resource conditions showed that the increase in population with an average growth of $3.5 \%$ per year, so the population density reaches $3,458 / \mathrm{km}$. Likewise related to the household waste affecting water quality pollution because people throw directly into the sea either latrines and household waste (kitchen) and there not yet organizing waste management both by society and the government.

Clusters of small islands have a potential for high-productivity natural resources, have specific properties that differ from the continent or large islands, including having limited freshwater resources, sensitive and vulnerable to external influences Both natural and due to human activities, such as storms and large waves, pollution, having endemic types of high ecological value, the water area is wider than the area of its land and does not have a hinterland far from the coast.

Improving the utilization of the resources of small islands and its waters for the economic interests of the region has caused environmental damage, which in turn also has an impact on the socio-economic conditions of the community. People who are on small island have different life patterns when compared to the people who are in Big Island for example Java Island which most of the people are farming, while the Seribu Islands mostly hang his life from the sea.

Based on the above results are supported by the results of research conducted by Dalu, and Shackleton that there is a pretty basic understanding of the contribution of natural resources to the resilience of the urban poor who live in coastal settlements implications on the economic level of the surrounding community [14]. Likewise, according to Malin Song, et al, that natural resources are prepared and designed for the audit office off of natural resources by the leaders [15].

\section{CONCLUSIONS}

Based on the findings of this study concluded that (1) the conditions and potential natural and human resources, especially the level of participation in the preservation of natural resources such as coral reefs identified in a state of disrepair. The cause of the damage due to degradation of mangroves and accumulation of household waste in the area of research, people's incomes are still far below the local minimum wage (UMR) locally, the quality of sea water in fairly good condition for grouper aquaculture, seaweed and others, as well as the majority of people respondents dispose of waste in the sea and its surroundings; (2) factors that may affect the condition of the natural resources in the form of an increase in population, household waste affecting water quality pollution because people throw directly into the sea either latrines and household waste (kitchen).

\section{REFERENCES}

[1] I. Santosa and U. J. Soedirman, "Strategic Management of Rural Community Empowerment: Based Local Resources," Int. Integr. Reg. Public Manag., vol. 25, no. 1, pp. 1-7, 2017.

[2] N. Erum and S. Hussain, "Corruption, Natural Resources and Economic Growth: Evidence from OIC Countries," Resour. Policy, vol. 63, no. 1, pp. 1-11, 2019.

[3] J. Meyer, "European Review of History: Revue Européenne d' histoire who should Pay for Pollution? The OECD, the European Communities and the Emergence of Environmental Policy in the Early 1970," Eur. Rev. Hist. Rev. Eur. d'histoire, vol. 63, 
no. 2, pp. 1-22, 2017.

[4] N. Thomas and M. Bull, "International Journal of Drug Policy Representations of women and drug use in policy : A critical policy analysis," Int. J. Drug Policy, vol. 56, no. 3, pp. 1-15, 2018.

[5] A. R. Vining and D. L. Weimer, "Policy Analysis," Int. Encycl. Soc. Behav. Sci., vol. 18 , pp. $1-8,2015$.

[6] S. M. Posner and C. Cvitanovic, "Evaluating the Impacts of Boundary-Spanning Activities at the Interface of Environmental Science and Policy: A Review of Progress and Future Research Needs," Environ. Sci. Policy, vol. 92, no. 2, pp. 1-8, 2016.

[7] M. Markantoni, A. Steiner, J. Elliot, and J. Farmer, "Geoforum Do Community Empowerment and Enabling State Policies Work in Practice? Insights from a Community Development Intervention in Rural Scotland," Geoforum, vol. 97, no. 1, pp. 142-154, 2018.

[8] D. B. E. Jr and E. Salvador, "International Journal of Educational Development Shifting the Perspective on Community-Based Management of Education: From Systems Theory to Social Capital and Community Empowerment," Int. J. Educ. Dev., vol. 64, no. 1, pp. 17-26, 2019.

[9] P. Iffah Farhana Abu Talib, Roshana Takim, Mohammad Fadhil Mohammada, "ScienceDirect Community Empowerment through Rehabilitation and Community Empowerment Rehabilitation Reconstruction in Social Sector of through Kuala Krai , Reconstruction in Social Sector of a," Procedia Eng., vol. 212, no. 2, pp. 294-301, 2018.

[10] C. Lessmann and A. Steinkraus, "The Geography of Natural Resources, Ethnic Inequality and Civil Conflicts,” Eur. J. Polit. Econ., vol. 18, no. 1, pp. 1-44, 2019.

[11] O. Zallé, "Natural Resources and Economic Growth in Africa : The Role of Institutional Quality and Human Capital," Resour. Policy, vol. 1, no. July, pp. 1-9, 2018.

[12] M. Danish, Awais, N. Mahmood, and J. Wu, "Science of the Total Environment Effect of Natural Resources, Renewable Energy and Economic Development on CO 2 Emissions in BRICS Countries," Sci. Total Environ., vol. 678, no. 1, pp. 632-638, 2019.

[13] L. E. Armey and R. M. Mcnab, "Expenditure Decentralization and Natural Resources," Q. Rev. Econ. Financ., vol. 2, no. 4, pp. 1-35, 2018.

[14] M. T. B. Dalu and C. M. Shackleton, "The Potential Use of Natural Resources in Urban Informal Settlements as Substitutes for Financial Capital During Flooding Emergencies," Phys. Chem. Earth, vol. 16, no. 2, pp. 1-10, 2018.

[15] M. Song, S. Zhu, J. Wang, and S. Wang, "China's Natural Resources Balance Sheet from the Perspective of Government Oversight: Based on the Analysis of Governance and Accounting Attributes," J. Environ. Manage., vol. 248, no. 1, pp. 1-16, 2019. 